\title{
FLIPPED CLASSROOM DAN APLIKASI SCHOOLOGY: ANALISIS KETERAMPILAN MENULIS TEKS BIOGRAFI
}

\author{
Fitria Febri Arianti ${ }^{1}$, Sutrimah ${ }^{2}$, Cahyo Hasanudin ${ }^{3}$ \\ IKIP PGRI Bojonegoro \\ Pos-el: fitria9802@gmail.com ${ }^{1}$,Sutrimah@yahoo.com ${ }^{2}$, \\ cahyo.hasanudin@ikippgribojonegoro.ac.id ${ }^{3}$
}

Diserahkan: 3 Juli 2020, Direvisi: 3 November 2020, Diterima: 11 Februari 2021

\begin{abstract}
This study aimed to investigate the students' skill in writing biography text in flipped classroom learning by using schoology apps at SMA Muhamadiyah 3 kedungadem. This study was qualitative research in form of case study in which twenty two students acted as the research subjects. Four students were chosen to be interviewed because their biography texts were appropriate with the indicators. Techniques in colleting data were observation, test, interview, and documentation. The data was validated by using triangulations of data source and method. Technique in analysing data used content analysis method that was started from data reduction, data presentation, drawing conclusion and verification. The result of study showed that the students' skills in writing biography texts were in line with the textbooks of Indonesian language subject for Senior and Vocational High School students. The conclusion of this study was
\end{abstract}


the structure of biography text written by the students in flipped classroom learning using schoology apps could be categorized as good structure. It could be viewed from 1) the structure of biography text had been included orientation, important events, and reorientation, 2) the biography texts written by the students had been appropriate with the original biography text about Ir Soekarno, 3) the grammatical rules of it used adverb of time, conjunction, verb, and pronoun, 4) the biography texts presented by giving overviews about the family of Ir Soekarno.

Keywords: flipped classroom learning, schoology apps, biography text

\begin{abstract}
Abstrak
Penelitian ini bertujuan untuk mengetahui keterampilan menulis teks biografi siswa SMA Muhammadiyah 3 Kedungadem dengan menggunakan flipped classroom dan aplikasi schoology. Penelitian ini adalah penelitian kualitatif dengan menggunakan studi kasus dengan jumlah subjek 22 siswa. Dari 22 siswa kemudian peneliti mengambil 4 siswa untuk diwawancarai dengan alasan teks biografi sesuai dengan indikator. Teknik pengumplan data menggunakan teknik observasi, metode tes, wawancara, dan dokumentasi. Data divaliditaskan dengan menggunakan triangulasi sumber data dan triangulasi metode. Teknik analisis data menggunakan metode contact analysis yang dimulai dari reduksi data, penyajian data, serta penarikan simpulan dan verifikasi. Simpulan pada penelitian ini adalah struktur teks biografi yang ditulis oleh siswa kelas X SMA Muhammadiyah 3 Kedungadem pada pembelajaran flipped classroom dengan menggunakan aplikasi schoology dapat dikategorikan baik. Hal ini dapat dilihat dari 1) struktur teks biografi sudah berisi orientasi, kejadian penting, dan reorientasi, 2) isi teks biografi yang ditulis oleh siswa sudah sesuai dengan isi teks biografi asli tentang Ir Soekarno, 3) Kaidah kebahasaan teks biografi siswa menggunakan keterangan waktu, konjungsi, verba dan pronominal, 4) pola penyajian teks biografi yang baru ditulis siswa dengan memberikan sudut pandang tentang silsilah keluarga Ir Soekarno.
\end{abstract}

Kata Kunci: flipped classroom, aplikasi schoology, teks biografi. 


\section{PENDAHULUAN}

Pembelajaran di sekolah mempunyai peranan yang sangat penting untuk siswa. Salah satunya yaitu peranan dalam mengembangkan keterampilan berbahasa. Proses belajar bahasa selalu dimulai dengan urutan menyimak, berbicara, membaca, dan menulis. Salah satu keterampilan berbahasa yang harus dikuasai adalah menulis. Menulis menurut Muthowiatin, Sutrimah, dan Hasanudin (2020: 35) adalah aktivitas penting yang bisa dilakukan melalui media. Menulis adalah cara untuk menuangkan gagasan atau ide yang disalurkan dalam bentuk media bahasa (Nurgiyantoro, 2001: 45). Salah satu contoh keterampilan menulis seperti menulis status dan komentar pada beranda facebook (Setiawan \& Zyuliantina, 2020: 98).

Aktivitas dalam menulis juga tertuang pada kurikulum terbaru yang berlaku di Indonesia, yaitu kurikulum 2013 atau sering disebut sebagai kurikulum K13. Sistem pada kurikulum K13 adalah sistem kurikulum berbasis teks. Sistem ini menurut Widiatmoko, Arwansyah, dan Widyaningsih (2020: 71) diharapkan mampu membuat siswa memiliki kemampuan aktif produktif melalui menulis. Salah satu bentuk kegiatan menulis pada pembelajaran kurikulum K13 adalah menulis teks biografi. Teks biografi adalah teks yang menceritakan kembali kejadian atau pengalaman masa lampau (Kosasih, 2016: 159). Teks biografi dapat disampaikan berdasarkan pengalaman langsung penutur atau penulisnya. Teks biografi diajarkan pada siswa kelas X semester II. Hal ini tercantum dalam kurikulum 2013 pada Sekolah Menengah Atas (SMA) mata pelajaran bahasa Indonesia pada KD 4.15 yaitu menyusun teks biografi tokoh.

Dalam pembelajaran menulis teks biografi siswa diharapkan dapat mengembangkan ide, gagasan, dan pikiran dalam tulisannya. Akan tetapi, berdasarkan hasil observasi siswa masih belum dapat menulis teks biografi dengan baik karena siswa belum bisa menuangkan ide ke dalam tulisan (teks biografi). Hasil observasi ini diperkuat oleh temuan Hartawan dalam Navia, Asri, \& Afnita, (2018: 
432) bahwa masih banyak siswa yang kesulitan dalam menentukan topik, menuangkan gagasan dalam bentuk tulisan.

Beberapa upaya dapat dilakukan untuk mengatasi permasalahan tersebut. Apalagi dalam kondisi pandemi dengan dibatasinya interaksi secara luring, banyak media berbasis daring yang dapat dioptimalkan. Salah satu metode belajar terbaru berbasis digital pada saat ini yang menggunakan video ajar sebagai media belajar di luar kelas adalah metode flipped classroom. Metode pembelajaran flipped classroom memberikan kemudahan siswa untuk mempelajari sumber belajar secara luas dan mudah. Kelebihan metode pembelajaran flipped classroom menurut Sales (2013: 234) adalah siswa bisa bertanggung jawab mengelola pembelajaran dan meningkatkan interaksi belajar antar siswa dalam satu kelompok, serta siswa dapat belajar melalui video pembelajaran. Menurut Hasanudin dan Fitrianingsih (2019: 32) penerapan flipped classroom memberikan inovasi dalam pembelajaran, karena dapat memotivasi dalam bentuk pembelajaran video dan dapat digunakan atau diakses untuk mengisi waktu luang dimana saja dan kapan saja.

Adapun kekurangan dari metode pembelajaran flipped classroom adalah, 1) untuk menonton video diperlukan koneksi internet yang bagus, 2) siswa mungkin perlu pendampingan dalam menonton video, agar ketika pemahamannya kurang ada yang bisa memberikan penjelasan terkait materi tersebut, 3) dalam implementasi di Indonesia flipped classroom hanya bisa diterapkan di sekolah yang sudah memiliki sarana dan prasarana yang memadai mengingat pada pembelajaran ini menuntut siswa untuk menonton video di rumah. Pemanfaatan flipped classroom dapat meningkatkan hasil belajar siswa. Hal tersebut didukung oleh hasil penelitian yang dilakukan oleh Farida, Alba, \& Zainuddin (2019: 109-121) yang menunjukkan bahwa penggunaan metode flipped classroom dapat membangun komunikasi dua arah antara siswa dan pengajar di luar jam pelajaran sehingga dapat meningkatkan aktivitas dan hasil belajar siswa serta menunjukkan adanya perubahan perilaku dan peningkatan keterampilan menulis teks biografi. 
Di era teknologi yang semakin berkembang ini terdapat beberapa situs yang dapat digunakan guru sebagai media pembelajaran. Salah satunya adalah schoology. Schoology adalah suatu situs yang menggabungkan fitur jejaring sosial dan manajemen pembelajaran sehingga dengan memanfaatkan schoology kita dapat berinteraksi sosial sekaligus belajar. Schoology memberi kebebasan pada guru dan siswa untuk melakukan pembelajaran dimana saja dan kapan saja. Adapun kelebihan dari schoology adalah, 1) pada aplikasi ini terdapat fasilitas absensi yang digunakan untuk mengecek kehadiran siswa dan fasilitas untuk melihat semua aktivitas siswa, pada saat pembelajaran online, 2) sebagai wadah kelompok kolaborasi siswa dan guru dapat terlibat di dalamnya, 3) schoology dapat diakses pada web browser apa saja, serta dapat terhubung dengan aplikasi apa saja.

Menurut Saddhono, Hasanudin, \& Fitrianingsih (2019: 368) kelebihan schoology adalah dapat membantu siswa untuk meningkatkan produktivitas dan akademik prestasi, karena dapat menyelesaikan tugas dengan lebih cepat, dan menyediakan akses untuk pembelajaran di luar kelas. Kolaborasi antara metode pembelajaran flipped classroom dan aplikasi schoology dapat mempermudah siswa dalam mendapatkan materi pelajaran di luar kelas. Siswa dapat mengunduh video pelajaran melalui aplikasi schoology dan memulai diskusi atau tanya jawab di aplikasi schoology dengan dipantau langsung oleh guru.

\section{KAJIAN LITERATUR}

\section{Teks Biografi}

Teks biografi merupakan cerita hidup atau riwayat hidup seseorang yang berupa tulisan (Zabadi dan Sutejo, 2014: 100). Menurut Wahono, Mafrukhi dan Sawali (2013: 2) teks biografi merupakan teks yang berupa fakta, baik berupa keistimewaan, perjalanan hidup, perjuangan, kesuksesan, dan rintangan. Tokoh dalam teks biografi menurut Rianto (2019: 63) bisa menjadi teladan untuk orang banyak. Dari pendapat di atas dapat disintesis bahwa 
teks biografi merupakan teks cerita hidup yang berupa fakta yang ditulis kembali oleh orang lain.

\section{Flipped classroom}

Flipped classroom merupakan model pembelajaran yang mengubah pekerjaan siswa yang seharusnya dikerjakan di kelas tetapi dikerjakan di luar kelas dan sama-sama dibimbing oleh guru atau dosen (Ridha, Setyosari, \& Kuswandi dalam Ario \& Azra, 2018: 84). Menurut Prayitno dan Maskudi (2016: 122) Flipped classroom adalah metode pembelajaran terbalik, dimana biasanya pembelajaran dilakukan di kelas tetapi metode ini melakukan pembelajaran di rumah. Flipped classroom merupakan pengenalan pembelajaran kepada siswa jika belajar tidak hanya di dalam kelas (Juniantari, Pujawan, dan Widhiasih, 2018: 198). Jadi, kesimpulannya flipped classroom merupakan pembelajaran yang bisa dilakukan dimana saja, tidak harus di kelas. Hasil penelitian Hasanudin \& Fitrianingsih (2018: 439) menunjukkan bahwa model pembelajaran flipped classroom yang dikolaborasi dengan aplikasi ScreencastO-Matic mampu meningkatkan verbal linguistik (kemamupuan berbahasa) mahasiswa.

\section{Schoology}

Schoology merupakan aplikasi online yang menawarkan pembelajaran gratis seperti di dalam kelas (Diani dalam Kusumantara, Santyadiputra, \& Sugihartini, 2017: 127). Schoology merupakan aplikasi online yang difokuskan pada sistem kerja sama untuk mengolah, membuat, dan berinteraksi untuk berbagi konten (Latifah dan Utami, 2019: 38). Menurut Putri, Jampel, dan Suartama (2014: 2) Schoology merupakan sistem web yang mudah digunakan untuk pembelajaran secara gratis. Jadi schoology merupakan situs pembelajaran yang mudah diakses dan digunakan.

\section{Penerapan Metode Flipped Classroom dan Aplikasi Schoology dalam Pembelajaran Menulis Teks Biografi}

Penerapan metode flipped classroom dan aplikasi schoology dalam pembelajaran menulis teks biografi dapat dijelaskan melalui 
langkah-langkah yaitu: (a) Siswa menonton video pembelajaran yang telah diunggah di aplikasi schoology dan mengerjakan soal di aplikasi yang suah disiapkan guru, (b) Siswa dapat menulis teks biografi sesuai dengan tayangan video, (c) Saat di kelas guru hanya mereviu hasil belajar siswa dengan mengutamakan keaktifan siswa yang dibuktikan dengan saling mengomentari hasil belajar yang telah mereka kerjakan di aplikasi, (d) Evaluasi hasil dari pembelajaran dengan metode flipped classroom dan aplikasi schoology.

\section{METODE PENELITIAN}

Penelitian ini adalah penelitian deskriptif kualitatif. Penelitian kualitatif merupakan jenis penelitian yang digunakan untuk meneliti kata-kata dan gambar (Moleong, 2015: 11) pada kondisi objek alamiah, dimana peneliti sebagai kunci (Sugiyono, 2015a: 9). Sumber data merupakan subjek darimana data diperoleh (Arikunto, 2006: 129). Sumber data dalam penelitian ini adalah siswa kelas X SMA Muhammadiyah 3 Kedungadem yang berupa hasil tes menulis teks biografi dan wawancara dengan siswa dilakukan melalui telepon. Data yang diperoleh pada penelitian ini adalah struktur teks biografi, kesesuaian isi dengan isi asli teks biografi, kaidah kebahasaan teks biografi, kesesuaian dengan pola penyajian teks biografi yang ditulis oleh siswa kelas X SMA Muhammadiyah 3 Kedungadem ketika diajar menggunakan metode flipped classroom dan aplikasi schoology. Subjek pada penelitian ini berjumlah 22 siswa. Dari 22 siswa kemudian diambil 4 siswa untuk diwawancarai dengan alasan keempat siswa tersebut memiliki kemampuan menulis teks biografi sudah bagus dan sesuai indikator. Prosedur pengumpulan data pada pengumpulan data pada penelitian ini dilakukan dengan cara observasi, tes, wawancara, dan dokumentasi.

\section{Observasi}

Teknik observasi menurut Sutopo (2006: 75) digunakan untuk menggali data dan informasi berupa peristiwa, aktivitas, tempat, benda, dan rekaman gambar. Observasi dapat dilakukan secara langsung maupun tidak langsung. Observasi dalam penelitian 
ini dilakukan secara daring untuk memperoleh gambaran yang jelas mengenai permasalahan yang sedang diteliti.

\section{Tes}

Tes merupakan pemberian sebuah pertanyaan lalu diberikan jawaban (Arikunto, 2006: 200). Metode tes digunakan untuk mengetahui keterampilan menulis teks biografi siswa kelas X SMA Muhammadiyah 3 Kedungadem. Tes menulis dilakukan oleh siswa secara individu setelah diajar menggunakan metode flipped classroom dan aplikasi schoology. Hasil tes kemudian dianalisis untuk mengetahui keterampilan menulis teks biografi. Adapun langkah-langkah yang dilakukan peneliti dalam mengumpulkan data dari tes yang dilakukan siswa yaitu: a). Siswa membuka aplikasi schoology, b). Siswa mengerjakan tes pada kolom aplikasi schoology, c). Hasil tes menulis dianalisis.

\section{Metode Wawancara}

Pada penelitian ini menggunakan wawancara tak berstruktur karena wawancara tak berstruktur pada umumnya dianggap sesuai dengan sifat siswa yang lebih senang menceritakan masalahnya, serta dalam melakukan wawancara tak berstruktur lebih bersifat bebas yang akan membuat siswa tidak merasa bosan. Langkahlangkah yang akan dilakukan oleh peneliti dalam mengumpulkan data melalui wawancara, yaitu: a). Menyusun pedoman wawancara tak berstruktur yang berupa garis besar dari permasalahan yang ingin ditanyakan, b). Wawancara dilakukan secara terang-terangan yaitu antara siswa sebagai subjek penelitian dan peneliti sebagai pewawancara, c). Wawancara dilakukan pada 4 siswa yang sesuai dengan indikator. Butir pertanyaan di kembangkan dari hasil menulis teks biografi yang telah dilakukan oleh siswa, d). Hasil wawancara dianalisis sehingga mendapatkan hal yang berhubungan dengan kreativitas siswa dalam menulis teks biografi.

\section{Metode Dokumentasi}

Metode dokumentasi dapat dikatakan sebagai metode pengumpulan data yang sumber datanya tertulis (Arikunto, 2006: 
158). Dokumen yang digunakan dalam penelitian ini adalah hasil tes berupa tulisan teks biografi yang dibuat oleh siswa dalam aplikasi schoology. Dokumen tersebut dianalisis untuk menjawab rumusan masalah.

Teknik analisis data pada penelitian ini merujuk pada teori Miles and Huberman dalam Sugiyono (2015b: 91) yang meliputi tiga analisis data yang terdiri dari reduksi data, penyajian data, dan penarikan simpulan. Reduksi data merupakan proses memilih, menyederhanakan, mengabstraki, dan mentransformasi data kasar yang diperoleh dari lapangan. Reduksi data dalam penelitian ini terdiri dari: a). Mengoreksi hasil pekerjaan siswa yang sesuai dengan indikator, b). Langkah selanjutnya yaitu melakukan wawancara kepada subjek penelitian yang memenuhi indikator penilaian, kemudian hasil wawancara itu disusun dan disederhanakan dengan menggunakan bahasa yang baik.

\section{Penyajian data}

Penyajian data merupakan data yang disampaikan lalu disimpulkan kemudian data tersebut diredupsi kembali untuk mencari kebenarannya. Penyajian data dalam tahap ini terdiri dari: a). Langkah pertama dalam penyajian data yaitu menyiapkan hasil pekerjaan siswa yang telah dipilih sesuai dengan indikator sebagai subjek dalam penelitian, b). Langkah selanjutnya yaitu menyajikan hasil wawancara yang telah dilakukan dengan siswa yang memenuhi indikator.

\section{Penarikan Kesimpulan/ Verifikasi}

Penarikan kesimpulan/ verifikasi merupakan strategi yang dilakukan agar setiap tahapan pengumpulan data perpadu dengan jelas, sehingga akan mencapai sesuai apa yang diinginkan. Penarikan kesimpulan dalam hal ini yaitu membandingkan hasil pekerjaan siswa yaitu menulis teks biografi dengan hasil wawancara kemudian ditarik simpulan.

\section{HASIL PENELITIAN DAN PEMBAHASAN}

Hasil teks biografi yang ditulis siswa pada penerapan model pembelajaran flipped classroom dengan menggunakan 
aplikasi schology memberikan kontribusi yang positif dalam proses pembelajaran. Aplikasi schoology sangat mengakomodasi proses pembelajaraan saat dikolaborasi dengan model pembelajaran flipped classroom. Siswa bisa mengakses materi, diskusi, dan mengumpulkan tugas dengan mudah melalui aplikasi schoology. Berikut tulisan teks biografi siswa pada aplikasi schoology.

\section{Hasil}

\section{Struktur Teks Biografi yang Ditulis Siswa}

Struktur teks biografi yang ditulis siswa dapat dilihat pada kutipan berikut.

"Ir. Soekarno merupaka presiden indonesia yang pertama. Ir. Soekarno lahir di Kota Surabaya pada tanggal 6 juni 1901. Ir. Soekarno menjabat menjadi presiden pada periode 1945 - 1967. Beliau wafat pada tanggal 21 juni 1970. Ir. Soekarno adalah orang yang pertama kali mencetuskan konsep pancasila sebagai dasar negara Indonesia. Beliau juga dikenal sebagai."

Pada lembar tes menulis teks biografi, siswa membuat teks biografi tentang Ir.Soekarno. Isi struktur teks biografi berisi tentang orientasi dan reorientasi. Berdasarkan struktur teks biografi yang ditulis oleh siswa, diketahui bahwa siswa membuat struktur teks biografi yang terdiri dari orientasi dan reorientasi sesuai pedoman penulisan teks biografi. Bentuk orientasi yang ditulis oleh siswa sesuai kutipan di atas adalah "Ir. Soekarno merupaka presiden indonesia yang pertama. Ir. Soekarno lahir di Kota Surabaya pada tanggal 6 juni 1901. Ir. Soekarno menjabat menjadi presiden pada periode 1945 - 1967. Beliau wafat pada tanggal 21 juni 1970.", Sedangkan bentuk reorientasi yang ditulis adalah "Ir. Soekarno adalah orang yang pertama kali mencetuskan konsep pancasila sebagai dasar negara Indonesia. Beliau juga dikenal sebagai." Ketika peneliti mengajukan pertanyaan alasan menulis teks biografi seperti itu, siswa menjelaskan bahwa dalam menulis teks biografi harus sesuai dengan struktur yang ada. Hal ini dapat dilihat pada kutipan wawancara berikut. 
$P$ : "Apakah kamu sudah memahami struktur teks biografi?"

S1 : "Sudah, Bu!"

$P$ : “Apa kamu tahu apa saja bagian dari struktur teksbiografi?"

S1: "Saya tahu, Bu"

$P$ : "Mengapa kamu menuliskan tentang tempat dan tanggal

lahir Ir. Soekarno?

S1 : "Karena itu termasuk orientasi Bu".

Struktur teks biografi yang ditulis oleh siswa menceritakan tentang riwayat hidup tokoh Ir. Soekarno yang termasuk orientasi dan terdapat kesimpulan jika Ir. Soekarno adalah bapak proklamator termasuk reorientasi. Struktur teks biografi ini sudah cukup sesuai dengan struktur teks biografi yang diungkapkan oleh Priyanto (2013: 40) bahwa struktur teks biografi yang baik yaitu terdiri dari orientasi, kejadian penting, dan reorientasi.

\section{Kesesuaian Isi dengan Isi Asli Teks Biografi}

Kesesuaian isi dengan isi asli teks biografi yang ditulis siswa dapat dilihat pada gambar berikut.

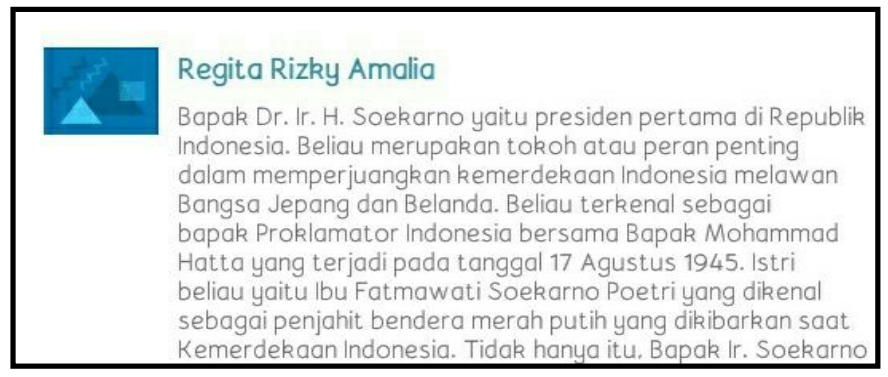

Gambar 1. Kesesuaian Isi dengan Isi Asli Teks

Pada lembar tes menulis teks biografi, siswa membuat kesesuaian isi dengan isi asli teks biografi sesuai dengan ciri-ciri teks biografi. Teks biografi ini berisi tentang informasi berdasarkan fakta yang ada dan hal-hal yang perlu diteladani. Dapat dilihat bahwa siswa membuat kesesuaian isi dengan isi asli teks biografi sesuai dengan ciri-ciri teks biografi. Ketika peneliti mengajukan pertanyaan, alasan menulis teks biografi tersebut, siswa menjelaskan bahwa di dalam 
teks biografi terdapat tiga ciri-ciri yaitu informasi berdasarkan fakta yang ada, hal-hal yang perlu diteladani, dan struktur yang jelas. Hal ini dapat dilihat pada kutipan wawancara berikut.

$P$ : "Apakah kamu memahami ciri-ciri teks biografi?"

S2: "Iya Bu, Saya paham!"

$P$ : "Mengapa kamu menuliskan jika Ir. Soekarno adalah presiden pertama Republik Indonesia?

S2: "Karena itu termasuk salah satu ciri-ciri teks biografi, yaitu menuliskan informasi berdasarkan fakta yang ada.

Ciri-ciri teks biografi yang ditulis oleh subjek 2 menceritakan jika Ir. Soekarno adalah presiden pertama Republik Indonesia, karena termasuk informasi berdasarkan fakta yang ada. Ciri-ciri teks biografi ini sudah sesuai dengan ciri-ciri teks biografi yang diungkapkan oleh Setianingsih (2017: 33) bahwa ciri-ciri teks biografi yang baik yaitu terdiri dari a). Teks biografi harus memuat informasi fakta tanda ada rekayasa, b). Memuat fakta hidup atau pengalaman hidup seorang tokoh yang patut diteladani, c). Teks biografi memiliki struktur teks yang jelas.

\section{Kaidah Kebahasaan Teks Biografi yang Ditulis Siswa}

Kaidah kebahasaan teks biografi yang ditulis oleh siswa dapat dilihat pada gambar berikut,

Ir. Soekarno Soekarno atau bung Karno lahir pada tanggal 6 Juni 1901 di Surabaya, Jawa Timur.

Ayah Soekarno bernama Soekemi Sosrodiharjo beliau merupakan seorang guru di Surabaya, sedangkan Ibu Soekarno bernama Ida Ayu Nyoman Rai

Setelah lulus Soekarno tinggal di rumah Haji Oemar Said Tjokroaminoto dan dari sanalah Soekarno kenal dengan dunia perjuangan yang membuat dirinya menjadi pejuang sejati 
Setelah masa jabatannya sebagai presiden Indonesia usai beliau menghabiskan waktunya di istana Bogor dan lama-kelamaan kesehatan beliau terus menurun

kata sifat

sampai akhirnya beliau menghembuskan nafas terakhirnya diRSPAD Gatot Subroto, Jakarta. Jenazah beliau kemudian dibawa ke Blitar, Jawa Timur untuk dimakamkan dekat dengan makam ibunya Ida Ayu Nyoman Rai. Gelar "Pahlawan Proklamasi” diberikan oleh pemerintah karena jasa-jasanya kepada bangsa Indonesia yang begitu besar

kalimat pasif

\section{Gambar 2 Kaidah Kebahasaan Teks Biografi}

Pada lembar tes menulis teks biografi, siswa membuat teks biografi sesuai dengan penggunaan kaidah kebahasaan teks biografi. Teks biografi ini berisi tentang kaidah kebahasaan teks biografi. Ketika peneliti mengajukan pertanyaan alasan menulis teks biografi seperti itu, siswa menjelaskan bahwa dalam menulis teks biografi harus sesuai dengan kaidah kebahasaan. Hal ini dapat dilihat pada kutipan wawancara berikut.

\section{$P \quad:$ :Apa kamu tahu apa yang dimaksud dengan kaidah kebahasaan teks biografi?"}

S3 : "Iya saya tahu, Bu"

$P \quad$ : "Mengapa kamu menggunakan kata beliau sebagai pengganti Ir. Soekarno?"

S3 : "Karena dalam kaidah kebahasaan teks biografi harus ada kata ganti atau pronomina".

Kaidah kebahasaan teks biografi yang ditulis oleh siswa menceritakan tentang Ir. Soekarno. Dalam teks biografi tersebut terdapat kata membuat sebagai kata kerja, kata waktunya sebagai kata sifat, kata beliau sebagai kata ganti Ir. Soekarno. Soekarno atau bung Karno lahir pada tanggal 6 Juni 1901 di Surabaya, Jawa Timur 
sebagai kalimat aktif, dan Gelar "Pahlawan Proklamasi" diberikan oleh pemerintah sebagai kalimat pasif”. Penggunaan kaidah kebahasaan teks biografi ini sudah sesuai dengan kaidah kebahasaan teks biografi. Rahman (2018: 77) menjelaskan bahwa penggunaan kaidah kebahasaan teks biografi terdiri dari a) menggunakan kata ganti atau pronominal, b) menggunakan kata kerja tindakan, c) menggunakan kata sifat, d) menggunakan kalimat aktif, dan e) menggunakan kalimat pasif.

\section{Kesesuaian dengan Pola Penyajian yang Baru Teks Biografi}

Kesesuaian dengan pola penyajian yang baru teks biografi siswa dapat dilihat pada tabel berikut.

Tabel 1. Pola Penyajian Teks Biografi

\begin{tabular}{cccc}
\hline \multicolumn{3}{c}{ Pola Penyajian } \\
\hline Alur & Sudut Pandang & Gaya Penceritaan & Fokus Penceritaan \\
\hline Maju & Orang ketiga & Deskriptif naratif & Latar belakang tokoh \\
\hline
\end{tabular}

Pada lembar tes menulis teks biografi, siswa membuat kesesuaian dengan pola penyajian yang baru biografi Ir. Soekarno. Teks biografi ini berisi tentang pengenalan silsilah keluarga Ir. Soekarno. Ketika peneliti mengajukan pertanyaan alasan menulis teks biografi seperti itu, siswa menjelaskan bahwa silsilah keluarga termasuk fokus penceritaan dalam teks biografi ini. Hal ini dapat dilihat pada kutipan wawancara berikut.

$P \quad$ : "Apa kamu tahu apa yang dimaksud dengan kesesuaian dengan pola penyajian yang baru biografi?"

S4 : "Iya saya tahu, Bu"

$P \quad$ : "Mengapa kamu menuliskan silsilah keluarga dalam teks biografi Ir. Soekarno?"

S4 : "Karena silsilah keluarga termasuk fokus penceritaan dalam teks biografi ini”.

Kesesuaian dengan pola penyajian yang baru biografi yang ditulis oleh subjek 4 menceritakan tentang pengenalan silsilah keluarga Ir. Soekarno. Penggunaan pola penyajian teks biografi ini sudah sesuai dengan pola penyajian teks biografi yang ditulis 
pada buku siswa bahasa Indonesia revisi 2017. Buku siswa bahasa Indonesia revisi 2017 menjelaskan bahwa pola penyajian teks biografi terdiri dari: a) alur, b) sudut pandang penceritaan, c) gaya penceritaan, dan d) fokus penceritaan.

\section{Pembahasan}

Merujuk pada teks biografi yang dikemukakan pada buku siswa bahasa Insonesia revisi 2017. Teks biografi yang ditulis oleh siswa kelas X SMA Muhammadiyah 3 Kedungadem sudah mengacu pada teks biografi sesuai teori dengan benar.

\section{Struktur Teks Biografi}

Pada struktur teks biografi, siswa menulis struktur teks biografi berdasarkan tentang riwayat hidup tokoh Ir. Soekarno yang termasuk orientasi, dan terdapat kesimpulan bahwa Ir. Soekarno adalah bapak proklamator termasuk struktur reorientasi. Struktur teks biografi menurut Suherli dkk. (2017: 215) terdiri dari orientasi (berisi informasi mengenai latar belakang kisah atau peristiwa), kejadian penting (berisi rangkaian peristiwa yang disusun secara kronologi) dan reorientasi (berisi pernyataan simpulan mengenai rangkaian peristiwa). Hal ini diperkuat oleh hasil penelitian Putri, dkk. (2018: 195) bahwa siswa sudah dapat menuliskan dengan lengkap struktur teks biografi seperti orientasi, urutan peristiwa, dan reorientasi. Hasil penelitian Puspitasari, Suwandi, dan Suhita (2018: 230) menunjukkan adanya peningkatan keterampilan siswa pada aspek kelengkapan struktur teks biografi di siklus II. Hasil penelitian Mulya, Hilal, dan Ariyani (2017: 12) menunjukkan bahwa portofolio yang disusun oleh siswa sudah menunjukkan struktur teks biografi dengan benar.

\section{Kesesuaian Isi dengan Isi Asli Teks Biografi sesuai dengan Ciri-Ciri}

Pada ciri-ciri teks biografi, siswa menulis ciri-ciri teks biografi berdasarkan cerita bahwa Ir. Soekarno adalah presiden pertama Republik Indonesia, karena termasuk informasi berdasarkan fakta yang ada. Menurut kemendikbud (2015: 277) ciri-ciri teks biografi 
yang baik yaitu uraian masalah yang dialami tokoh harus jelas teks biografi yang disajikan harus bisa memikat menarik. Hasil penelitian Dwinita, Yakob, dan Hidayat (2019: 17) menunjukkan bahwa siswa sudah mampu menulis teks biografi berdasarkan pemahaman isi teks biografi. Hasil penelitian Larasakti, Gumono, dan Susetyo (2019: 348) menunjukkan bahwa isi teks biografi yang ditulis oleh siswa dapat dikategorikan dengan predikat baik. Hasil penelitian Fajri, Asri, dan Afnita (2018: 159) menunjukkan bahwa guru memberikan penguatan dan komentar terhadap isi teks biografi yang ditulis oleh siswa. Hasil penelitian Navia, Asri dan Afnita (2018: 437) menunjukkan bahwa siswa sudah menuliskan isi teks biografi secara lengkap.

\section{Kaidah Kebahasaan Teks Biografi}

Pada kaidah kebahasaan teks biografi, siswa menulis teks biografi berdasarkan kata membuat sebagai kata kerja, kata waktunya sebagai kata sifat, kata beliau sebagai kata ganti, Ir. Soekarno. Soekarno atau bung Karno lahir pada tanggal 6 Juni 1901 di Surabaya, Jawa Timur sebagai kalimat aktif, dan Gelar "Pahlawan Proklamasi" diberikan oleh pemerintah sebagai kalimat pasif”. Kaidah kebahasaan teks biografi menurut Sudarti (2019: 273) menggunakan keterangan waktu, menggunakan konjungsi untuk mengurutkan peristiwa, menggunakan verba atau kata kerja, menggunakan pronominal atau kata ganti. Hal ini diperkuat oleh hasil penelitian Affrilia, Syambasril, dan Wartinigsih (2019: 5) bahwa kaidah kebahasaan teks biografi meliputi penggunaan kata hubung, penggunaan kata rujuk, penggunaan kata keterangan waktu, dan penggunaan kata kerja. Hasil penelitian Subardi (2017: 1) menunjukkan bahwa terdapat hubungan positif antara penguasaan ciri-ciri kebahasaan teks biografi dengan keterampilan menulis teks biografi. Hasil penelitian Widyasari, Martono, dan Syambasril (2020: 9) menunjukkan bahwa kaidah kebahasaan teks biografi yang ditulis siswa dapat dikategorikan baik.

\section{Kesesuaian Dengan Pola Penyajian Yang Baru Biografi}

Pada pola penyajian teks biografi, siswa menulis berdasarkan pengenalan silsilah keluarga Ir. Soekarno. Menurut Tim Super Tentor 
(2018: 118) pola penyajian biografi yaitu penyajian dengan penjelasan gambaran kisah dan penceritaan kisah tokoh. Hasil penelitian Mulyani, Syambasril, Syahrani (2019: 7) menunjukkan bahwa siswa dapat membuat pola penyajian yang berbeda. Hasil penelitian Azizah (2018: 1) menunjukkan bahwa siswa menemukan pola penyajian karakter unggul tokoh dan dapat menggunakan cara yang berbeda.

\section{PENUTUP}

Struktur teks biografi yang ditulis oleh siswa kelas X SMA Muhammadiyah 3 Kedungadem pada pembelajaran flipped classroom dengan menggunakan aplikasi schoology dapat dikategorikan baik. Hal ini dapat dilihat dari 1) struktur teks biografi sudah berisi orientasi, kejadian penting, dan reorientasi, 2) isi teks biografi yang ditulis oleh siswa sudah sesuai dengan isi teks biografi asli tentang Ir Soekarno, 3) Kaidah kebahasaan teks biografi siswa menggunakan keterangan waktu, konjungsi, verba dan pronominal, 4) pola penyajian teks biografi yang baru ditulis siswa dengan memberikan sudut pandang tentang silsilah keluarga Ir Soekarno.

\section{DAFTAR PUSTAKA}

Affrilia, W., Syambasril, dan Wartinigsih, A. (2019). Kemampuan menulis teks biografi siswa kelas X SMA Negeri 8 Pontianak. Jurnal Pendidikan dan Pembelajaran Khatulistiwa, 8(9), 1-10. Retrieved from https://jurnal.untan.ac.id/index.php/jpdpb/ article/view/35923/75676583113.

Aminoto, T., \& Pathoni, H. (2014). Penerapan media e-learning berbasis schoology untuk meningkatkan aktivitas dan hasil belajar materi usaha dan energi di kelas XI SMA N 10 Kota Jambi. Jurnal sainmatika, 8(1), 13-29. https://www.neliti.com/ publications/221167/ penerapan-media-e-learning-berbasisschoology-untuk-meningkatkan-aktivitas-dan-h

Arikunto, S. (2006). Prosedur penelitian suatu pendekatan praktik. Jakarta: Rineka cipta. 
Ario, M. dan Azra, A. (2018). Pengaruh pembelajaran flipped classroom terhadap hasil belajar kalkulus integral mahasiswa pendidikan matematika. Jurnal ilmiah pendidikan matematika, $1(2), 83-88$.

Azizah, A. F. N. (2018). Pembelajaran menceritakan kembali isi teks biografi dengan menggunakan media video blog (vlog) pada siswa kelas X SMAN 1 Soreang tahun pelajaran 2017/2018 (Skripsi. Universitas Pasundan, Bandung, Indonesia). Retrieved from http://repository.unpas.ac.id/39241/.

Dwinita, R., Yakob, M., dan Hidayat, M. T. (2019). Kemampuan siswa Kelas X SMA Negeri 4 Langsa menulis teks biografi. Jurnal Samudra Bahasa, 2(2), 13-20. Retrieved from https://www. ejurnalunsam.id/index.php/ JSB/article/view/1627/1209.

Fajri, M. I., Asri, Y., dan Afnita. (2018). Pengaruh teknik copy the master terhadap keterampilan menulis teks biografi siswa kelas X MAN 1 Padang. Jurnal Pendidikan Bahasa Dan Sastra, 7(3), 158-162. Retrieved from http://103.216.87.80/index.php/pbs/article/ view/100726/ 100223.

Farida, R., Alba, A., \& Zainuddin, Z. (2019). Pengembangan model pembelajaran flipped classroom dengan taksonomi bloom pada mata kuliah sistem politik Indonesia. Jurnal dimensi pendidikan dan pembelajaran, 7(2), 109-121. http://journal. umpo.ac.id/index.php/ dimensi/article/view/1809

Hasanudin, C., dan Fitrianingsih, A. (2018). The implementation of flipped classroom using screencast-omatic to improve students' verbal linguistic intelligence. International Journal of Engineering \& Technology, 7(4), 435-439. https://doi. org/10.14419/ijet.v7i4.15. 23602.

Hasanudin, C., Fitrianingsih, A. (2019). Analisis gaya belajar mahasiswa pada pembelajaran flipped classroom. Jurnal pendidikan edutama, 4(1), 31-36. https://ejurnal. ikippgribojonegoro.ac.id/index.php/JPE/ article/view/364

Juniantari, M., Pujawan, I. G.N., \& Widhisih, I. D. A. G. (2018). Pengaruh pendekatan flipped classroom terhadap 
pemahaman konsep matematika siswa SMA. Jurnal of education technology, 2(4), 19-204. https://ejournal.undiksha. ac.id/index.php/JET/article/view/ 17855.

Kemendikbud. (2015). Buku Guru: Bahasa Indonesia. Jakarta: Balitbang Kemdikbud.

Kosasih, E. (2016). Jenis-jenis Teks Edisi II. Bandung: Yrama Widya.

Kusumantara, K. S., Santyadiputra, G. S., \& Sugihartono, N. (2017). Pengaruh e-learning schoology terhadap hasil belajar simulasi digital dengan model pembelajaran savi. Jurnal pendidikan teknologi dan kejuruan, 14(2), 126-135. https://ejournal. undiksha.ac.id/index.php/JPTK/article/view/10387

Larasakti, S., Gumono, dan Susetyo (2019). Kemampuan menulis teks biografi siswa kelas X SMAN 3 Bengkulu Tengah tahun 2019. Jurnal Ilmiah Korpus, 3(3), 342-350. Retrieved from https:// ejournal.unib.ac.id/index.php/korpus/article/view/8399/5873.

Latifah, S., \& Utami Ardini. (2019). Pengembangan bahan ajar interaktif berbasis media sosial schoology. Jurnal science and mathematics education, 02(1), 36-45. http://ejournal. radenintan.ac.id/index.php/IJSME/article/view/3924

Moleong, L. (2015). Metode penelitian kualitatif. Bandung: PT. Remaja Rosdakarya Bandung.

Mulya, S. V., Hilal, I., dan Ariyani, F. (2017). Pembelajaran menulis teks biografi siswa kelas VIII SMP Global Madani Bandar Lampung. Jurnal Kata (Bahasa, Sastra, dan Pembelajarannya), 5(2), 1-12. Retrieved from http://jurnal.fkip.unila.ac.id/index.php/ BINDO1/article/view/14250.

Mulyani, T., Syambasril, Syahrani, A. (2019). Pelaksanaan pembelajaran teks biografi pada siswa kelas X IIS1 di SMA Santun Untan Pontianak. Jurnal pendidikan dan pembelajaran khatulistiwa, 8(3), 1-11. Retrieved from https://jurnal.untan.ac.id/index. php/jpdpb/article/view/ 32243/75676580744.

Muthowiatin, A., Sutrimah, \& Hasanudin, C. (2020). Penerapan metode quantum: Bagaimana siswa menulis teks 
negosiasi?. Tabasa: Jurnal Bahasa, Sastra Indonesia, dan Pengajarannya, 1(1), 35-47. Retrieved from http://ejournal. iainsurakarta.ac.id/index.php/tabasa/article/view/2590.

Navia, Y., Asri Y., \& Afnita. (2018). Pengaruh penggunaan strategi pembelajaran inkuiri terhadap keterampilan menulis teks biografi. Jurnal pendidikan bahasa dan sastra Indonesia, 7(3), 431-439. http://ejournal.unp.ac.id/index.php/pbs/article/ view/100767.

Nurgiyantoro, B. . (2001). Penilaian dalan Pengajaran Bahasa dan Sastra. Yoggyakarta: BPFE

Prayitno, E., \& Masduki, L. R. (2016). Pengembangan media blended learning dengan model flipped classroom pada mata kuliah pendidikan matematika II. Jurnal ilmiah pendidikan matematika, 1(2), 121-126. http://103.98.176.9/index.php/ JIPMat/article/view/1238

Priyanto, D. (2013). Bahasa Indonesia untuk SMA/MA dan SMK/SMAK semester 2. Surakarta, Indonesia: Putra Nugraha.

Puspitasari, P. D., Suwandi, S. \& Suhita, R. (2018). Penerapan model pembelajaran think talk write dalam pembelajaran menceritakan kembali isi teks biografi dengan media cetak. Jurnal bahasa, sastra, dan pengajarannya, 6(1), 232-244. https://jurnal.uns.ac.id/ Basastra/article/view/37717

Putri, N. W. M. A., Jampel, N., \& Suartama, I, K. (2014). Pengembangane-learning berbasis schoology pada mata pelajaran Ipa kelas VIII di SMP Negeri 1 Seririt. Jurnal teknologi pendidikan, 2(1), 1-11. https://ejournal.undiksha. ac.id/index.php/JEU/article/view/3796

Putri, N., dkk. (2018). Pengaruh penggunaan model discovery learning berbantuan media audiovisual terhadap keterampilan menulis teks biografi siswa kelas X SMA Negeri 12 Padang. Jurnal Pendidikan Bahasa Dan Sastra Indonesia, 7(3), 192-198. Retrieved from http://103.216.87.80/index.php/pbs/article/ view/100731. 
Rahman, T. (2018). Teks dalam Kajian Struktur dan Kebahasaan. Semarang, Indonesia: Pilar Nusantara.

Rianto, T. (2019). Cara Cepat Menguasai Bahasa Indonesia SMA/MA Kelas X, XI, XII. Jakarta, Indonesia: PT Bumi Aksara.

Saddhono, K., Hasanudin, C., Fitrianingsih, A. (2019). The ability to think creatively on SSCS using schoology Apps, how is the student's language metacognitive awareness? Ingénierie des Systèmes d'Information, 24(4), 367-375. https://doi. org/10.18280/isi.240402.

Sales, N. (2013). Flipping the Classroom: Revolutionising Legal Research Training. Legal Information Management, 13(4), 231-235. https://doi.org/10.1017/S1472669613000534.

Sari, S. D., Utami, A. S., \& Sunaryo, H. (2019). Peningkatan keterampilan menulis teks biografi melalui model think talk write pada peserta didik kelas X IPA 2 SMA N 09 Malang. PBSI, 7(1), 65-76. http://lppm-unissula.com/jurnal.unissula. ac.id/index.php/jpbsi/article/view/ 7431

Setianingsih. (2017). Medali sarana belajar berprestasi. Surakarta, Indonesia: Indonesia Jaya.

Setiawan, K., \& Zyuliantina, W. (2020). Analisis kesalahan berbahasa Indonesia pada status dan komentar di facebook. Tabasa: Jurnal Bahasa, Sastra Indonesia, dan Pengajarannya, 1(1), 96109. Retrieved from http://ejournal.iainsurakarta.ac.id/index. php/tabasa/ article/view/2605.

Subardi, D. (2017). hubungan antara penguasaan ciri-ciri kebahasaan dengan keterampilan menulis teks biografi pada siswa kelas $\mathrm{X}$ SMA Negeri 3 Bogor. Jurnal Online Mahasiswa (JOM) Bidang Pendidikan Bahasa \& Sastra Indonesia, 2(2). Retrieved from https://jom.unpak.ac.id/index.php/bahasaindonesia/article/ view/795.

Sudarti, N. W. (2019). Analisis struktur dan kaidah kebahasaan teks cerita ulang biografi karya mahasiswa program studi bimbingan konseling IKIP PGRI Bali. Widyadari: Jurnal 
pendidikan. 20 (2), 270-277. https://ojs.ikippgribali.ac.id/ index.php/widyadari/article/view/502

Sugiyono. (2015a). Metode penelitian kuanlitatif kualitatif dan r\&d. Bandung: Alfabeta Bandung. . (2015b). Memahami penelitian kualitatif. Bandung: Alfabeta.

Suherli, dkk. (2017). Bahasa Indonesia. Jakarta : Kementerian pendidikan dan kebudayaan.

Sutopo, H.B. (2006). Metodologi Penelitian Kualitatif: Dasar Teori dan Terapannya dalam Penelitian. Surakarta: Universitas Sebelas Maret.

Tim Super Tentor. (2018). Top One Ulangan Harian: Pilihan Cerdas Menjadi Bintang Kelas. Jakarta, Indonesia: PT Bintang Wahyu.

Wahono, Mafrukhi, dan Sawali. (2013). Mahir Berbahasa Indonesia untuk SMP/MTS Kelas VII. Jakarta: Erlangga

Widiatmoko, D., Arwansyah, Y. B., \& Widyaningsih, N. (2020). Pengembangan kartu bergambar tiga dimensi sebagai media pembelajaran menulis teks berita. Tabasa: Jurnal Bahasa, Sastra Indonesia, dan Pengajarannya, 1(1), 70-80. Retrieved from http://ejournal.iainsurakarta.ac.id/index.php/tabasa/ article/view/ 2618.

Widyasari, L., Martono, dan Syambasril. (2020). Kemampuan menulis teks biografi siswa kelas x SMA Negeri 1 Selakau Kabupaten Sambas. Jurnal Pendidikan dan Pembelajaran Khatulistiwa, 9(12), 1-9. Retrieved from https://jurnal.untan.ac.id/index.php/ jpdpb/article/view/44011/ 75676587807.

Zabadi, F. dan Sutejo. (2014). Bahasa Indonesia Wahana Pengetahuan untuk SMP/MTs Kelas VIII. Jakarta: Kementrian Pendidikan dan Kebudayaan. 